\title{
Behavior of Juvenile and Mature Eucalyptus cloeziana Wood Subjected to Drastic Drying
}

\author{
Bruno Charles Dias Soares ${ }^{1}$ (D), José Tarcísio Lima ${ }^{1}$ (D), \\ Maria Fernanda Vieira Rocha ${ }^{1}$ (D), Ana Clara Caxito de Araújo ${ }^{1}$ (D), \\ Taís Regina Lima Abreu Veiga ${ }^{1}$ (D) \\ ${ }^{1}$ Universidade Federal de Lavras - UFLA, Lavras/MG, Brasil
}

\begin{abstract}
This study aimed to evaluate the behavior of samples of juvenile and mature Eucalyptus cloeziana wood when subjected to the drying process, and the influence of the anatomy on that behavior. In order to do this, saturated specimens from this woods measuring $10 \times 5 \times 1 \mathrm{~cm}$ were subjected to drastic drying at $100{ }^{\circ} \mathrm{C}$, where the drying rates and the end check scores in different steps of the process were obtained. The fibers and vessels morphology, initial moisture and basic density were analyzed to help understanding the data obtained in the drying test. The juvenile wood presented 26\% higher drying rate and 21\% smaller drying time, also 53\% higher end check score. Smaller fibers length and fibers wall thickness, higher vessels frequency and smaller vessels diameter were associated with higher total drying rate and water adsorption, as well as with the higher end check score.
\end{abstract}

Keywords: drying rate, end check, fiber, vessel. 


\section{INTRODUCTION}

The varied anatomical composition and the different organization forms of the anatomical components in the trunk result in the wood heterogeneity. Depending on the moisture take up or release, the wood behaves differently according to the orthotropic directions: radial, tangential and axial (Kollmann \& Côté, 1968). This heterogeneity is potentiated over the years by the wood formation process from the cambium.

It is known that a wood load to be subjected to conventional kiln-drying should consist of pieces from the same species (Pratt, 1974) or, if they are from different species, which have similar properties (Eleoterio et al., 2015). However, it is also known that there are variations in the wood properties within the log, which in many cases exceed the average variations among species (Souza et al., 2017). Among these, special attention should be paid to the differences between juvenile and mature wood properties.

The juvenile wood consists of a central stem region with lower density (Vidaurre et al., 2011), the fibers show lower wall thickness, smaller length (Trevisan et al., 2017) and greater microfibril angle in the layer 2 of the secondary cell wall (Souza et al., 2017), compared to mature wood. Juvenile wood is formed in the first years of tree life by the physiologically immature cambium (Panshin \& De Zeeuw, 1980) and its proportion in the trunk varies according to the species studied (Souza et al., 2017).

The moisture release during drying generates tensions in the internal and external regions of the pieces, causing defects such as warping, check and case hardening (Kollmann \& Côté, 1968). The understanding of this process effect on the wood allows its control, so that the dry wood is free of tensions and defects caused by the moisture loss.

The greater or lower onset of drying stresses is due to the intrinsic characteristics of permeability, anatomical composition, density and mechanical strength of the wood together with drying conditions to which the material is subjected (Kollmann \& Côté, 1968); thus it may be influenced by the presence in a greater or lesser proportion of juvenile wood.

The understanding of the difference in behavior between juvenile and mature wood is important for the industry in terms of drying optimization. Knowing these differences one can choose to carry out the classification of juvenile and mature wood boards, making possible the drying of these woods in separate loads.

Soares et al. (2016) evaluated the behavior of juvenile and mature $E$. saligna wood during drastic drying and concluded that there is a difference between these materials in terms of drying rate, drying time and end check score. Considering the lower parameters drying potential and initial temperature found for mature wood, Soares et al. (2016) recommended a smoother drying schedule for this wood than for juvenile wood.

Eleoterio et al. (2015) suggested initial temperature of $40.0^{\circ} \mathrm{C}$, final temperature of $68.7^{\circ} \mathrm{C}$ and drying potential of 2.16 in a drying schedule for E. cloeziana at 17 years of age. The same authors also suggested values of $46.5^{\circ} \mathrm{C}, 73.6^{\circ} \mathrm{C}$ and 2.66 (initial temperature, final temperature and drying potential, respectively) for the 8-year-old E. grandis $\times$ E. urophylla hybrid. That is, the authors indicated more drastic parameters for 8 -year-old wood than for 17-year-old wood, which may have a higher percentage of mature wood in the trunk. Disregarding the specie factor, this result corroborates with Soares et al. (2016).

Considering the importance of knowing the differences in behavior of the juvenile and mature wood during drying and the possibility of applying this knowledge to improve wood processing and utilization, little has been published, especially regarding the Eucalyptus cloeziana wood.

In this context, the aim of the present study was to quantify the difference between the behavior of juvenile and mature E. cloeziana woods separately subjected to drastic drying regarding the drying time, drying rate and occurrence of end check. Furthermore, fibers and vessels morphologies, basic density and initial moisture were determined for a better understanding of these differences.

\section{MATERIAL AND METHODS}

\subsection{Material obtainment and preparation}

Two logs of E. cloeziana were randomly selected and felled at 37 years of age. This material came from experimental plantation of the Campus of the Federal University of Lavras, located in the municipality of Lavras, Minas Gerais state, Brazil, $21^{\circ} 14^{\prime} 4^{\prime \prime}$ S and $44^{\circ} 59^{\prime} 5^{\prime \prime} \mathrm{W}$. 
Height and diameter at breast heights (DBH) of the trees were measured, with tree 1 measuring $20 \mathrm{~m}$ height and $44 \mathrm{~cm} \mathrm{DBH}$, while tree 2 was $28 \mathrm{~m}$ height and $59 \mathrm{~cm} \mathrm{DBH}$.

The trunks were split into 3-m logs and the basal logs were used for the preparation of specimens. The logs cutting was performed by a vertical band saw by the method alternate and parallel to the log center in order to obtain the boards, which had dimensions of $300 \mathrm{~cm}$ length, $2.5 \mathrm{~cm}$ thickness and varied width according to the logs diameters. These boards were sawed again by a table saw until reaching dimensions of $100 \mathrm{~cm} \times$ $20 \mathrm{~cm} \times 2.5 \mathrm{~cm}$ and then were planed until reaching the final thickness of $1.0 \mathrm{~cm}$.

The boards were separated as being from juvenile or mature wood, considering the determination made by Souza et al. (2017), based on the radial variation of the fibers length from the same logs used in the present study. According to these authors, the transition in E. cloeziana occurred in the fourteenth growth ring, serving as a practical definition for separating the boards during the logs saw and then be subjected to drying.

For the production of specimens, six boards $(100 \mathrm{~cm} \times 20 \mathrm{~cm} \times 1 \mathrm{~cm})$ from each log were used, being three boards representing the juvenile wood and another three representing the mature wood. All processing of the boards was performed with the minimum interval between stages in order to minimize moisture loss.

Six specimens were prepared from each $100 \mathrm{~cm} \times 20 \mathrm{~cm} \times$ $1 \mathrm{~cm}$ board, of which two were used to determine the initial moisture (A), two for the drying test (B) and two for the determination of the basic density (C), as shown in Figure 1. Thus, a total of twelve specimens were used per wood in each analysis. This methodology of drastic drying is adapted from Barbosa et al. (2005).

After preparation, the specimens were placed in containers with water for approximately 36 hours so that they remained saturated until the drastic drying test.

$$
\begin{array}{|l|l|l|l|l|l|}
\hline \mathrm{D} & \mathrm{B} & \mathrm{C} & \mathrm{A} & \mathrm{B} & \mathrm{C} \\
\hline
\end{array}
$$

Figure 1. Positions of samples on a board for drastic drying test. (A) Specimen for determination of initial moisture $(50 \times 50 \times 10 \mathrm{~mm})$; (B) specimen for oven drying at $100{ }^{\circ} \mathrm{C}(100 \times 50 \times 10 \mathrm{~mm})$; (C) specimen for determination of basic density $(50 \times 50 \times 10 \mathrm{~mm})$ (Barbosa et al., 2005); and (D) sample for anatomical analysis.
Also from the boards of $100 \mathrm{~cm} \times 20 \mathrm{~cm} \times 1 \mathrm{~cm}$, twelve cubes with dimensions of $1.0 \mathrm{~cm} \times 1.0 \mathrm{~cm} \times$ $1.0 \mathrm{~cm}(\mathrm{D})$ were produced representing each wood type for the anatomical analyses (Figure 1), being stored in a climatic chamber at a temperature of $20 \pm 2{ }^{\circ} \mathrm{C}$ and $65 \pm 5 \%$ relative humidity.

\subsection{Drastic drying test}

Drastic drying methodology was used in order to evaluate the wood behavior when subjected to drying (Barbosa et al., 2005). This methodology consists of subjecting green wood specimens measuring $100 \mathrm{~mm}$ $\times 50 \mathrm{~mm} \times 10 \mathrm{~mm}$ to a temperature of $100{ }^{\circ} \mathrm{C}$ in dry heat ovens and observing the drying times and the onset of defects inasmuch as the wood reaches preset moisture of $30 \%$ and $5 \%$ (dry basis).

The initial and final moistures of specimens were determined using the gravimetric method, and the basic density determination was performed according to NBR 11941-02 standard (ABNT, 2003).

The specimens were subjected to drying in a laboratory oven at $100 \pm 3{ }^{\circ} \mathrm{C}$, with convection system. During drastic drying, the moisture loss and the end check progress were monitored periodically (every 30 min between initial moisture and 30\% moisture, every 60 min between $30 \%$ and $15 \%$ moisture, every 120 min between $15 \%$ and $5 \%$ moisture). The measuring of the check opening was made using a feeler gauge and the check length using a digital pachymeter, always considering the highest occurrence intensity. At the same periodicity, the weight loss was determined until the specimens reached 5\% moisture.

The end check values were transformed into scores, according to the criteria of Table 1. Moisture loss values were used to calculate the drying rate. Based on these values, the variables of the drastic drying test (Table 2) were calculated.

Table 1. Score assigned to the end check magnitudes occurred in the specimens subjected to drastic drying test (Barbosa et al., 2005).

\begin{tabular}{cl}
\hline Score & \multicolumn{1}{c|}{ End check } \\
\hline 1 & Absent \\
2 & $\mathrm{CL}<5.0$ and $\mathrm{CW}<0.5$ \\
3 & $\mathrm{CL}>5.0$ and $\mathrm{CW}<0.5$ \\
4 & $\mathrm{CL}<5.0$ and $0.5<\mathrm{CW}<1.0$ \\
\hline 5 & $\mathrm{CL}>5.0$ and $0.5<\mathrm{CW}<1.0$ \\
6 & $\mathrm{CL}>5.0$ and $\mathrm{CW}>1.0$ \\
\hline
\end{tabular}

$\mathrm{CL}=$ check length $(\mathrm{mm}) ; \mathrm{CW}=$ check width $(\mathrm{mm})$. 
Table 2. Variables of the drastic drying test (Barbosa et al., 2005).

\begin{tabular}{|c|c|c|c|}
\hline Variable & Description & Moisture range & Unit \\
\hline IM & Initial moisture & Green & $\%$ \\
\hline $\mathrm{T} 1$ & Drying time & IM to $5 \%$ & $\mathrm{~h}$ \\
\hline $\mathrm{T} 2$ & Drying time & IM to $30 \%$ & $\mathrm{~h}$ \\
\hline T3 & Drying time & $30 \%$ to $5 \%$ & $\mathrm{~h}$ \\
\hline $\mathrm{R} 1$ & Drying rate & IM to $5 \%$ & g. $\mathrm{cm}^{-2} \cdot \mathrm{h}^{-1}$ \\
\hline $\mathrm{R} 2$ & Drying rate & IM to $30 \%$ & g. $\mathrm{cm}^{-2} \cdot \mathrm{h}^{-1}$ \\
\hline R3 & Drying rate & $30 \%$ to $5 \%$ & g. $\mathrm{cm}^{-2} \cdot \mathrm{h}^{-1}$ \\
\hline $\mathrm{C} 1$ & End check & IM to $5 \%$ & score \\
\hline $\mathrm{C} 2$ & End check & IM to $30 \%$ & score \\
\hline $\mathrm{C} 3$ & End check & $30 \%$ to $5 \%$ & score \\
\hline
\end{tabular}

The drying rate was calculated according to Equations 1,2 and 3 (Barbosa et al., 2005).

Drying rate up to $5 \%$ moisture:

$\mathrm{R}_{1}=\frac{\mathrm{m}_{\mathrm{i}}-\mathrm{m}_{5}}{\mathrm{~T}_{1} \times 100}$

Drying rate up to $30 \%$ moisture:

$\mathrm{R}_{2}=\frac{\mathrm{m}_{\mathrm{i}}-\mathrm{m}_{30}}{\mathrm{~T}_{2} \times 100}$

Drying rate from $30 \%$ to $5 \%$ moisture:

$\mathrm{R}_{3}=\frac{\mathrm{m}_{30}-\mathrm{m}_{5}}{\mathrm{~T}_{3} \times 100}$

Where: $m_{i}=$ specimen weight at initial moisture (g); $m_{30}=$ specimen weight at $30 \%$ moisture $(\mathrm{g}) ; m_{5}=$ specimen weight at $5 \%$ moisture $(\mathrm{g}) ; T_{1}=$ drying time of initial moisture up to $5 \%(\mathrm{~h}) ; T_{2}=$ drying time of initial moisture up to $30 \%(\mathrm{~h}) ; T_{3}=$ drying time from $30 \%$ to $5 \%$ moisture (h); $100=$ surface area of the specimen $\left(\mathrm{cm}^{2}\right)$.

\subsection{Anatomical analysis}

From each cube measuring $1.0 \mathrm{~cm} \times 1.0 \mathrm{~cm} \times 1.0 \mathrm{~cm}$ (Figure 1) from the juvenile and mature woods, one sample with approximate dimensions of $1.0 \mathrm{~cm} \times 0.5 \mathrm{~cm}$ $\times 0.5 \mathrm{~cm}$ were sliced with a chisel for visualization and measurement of ray-vessel pits in radial section on scanning electron microscopy (SEM). One sample with the same dimensions aforementioned was also taken in order to obtain images of the transverse plane, in which the vessels frequency and vessels diameter could be determined.

Small woodchips were removed from each cube of $1.0 \mathrm{~cm} \times 1.0 \mathrm{~cm} \times 1.0 \mathrm{~cm}$ for determination of fibers length, fibers wall thickness, fibers lumen diameter and vessel elements length, using the technique of maceration with hydrogen peroxide (30 volumes) and acetic acid (P.A.) at 1:1 ratio in order to enable measurement (Franklin, 1945). Temporary slides were made for measuring fibers length, fibers wall thickness, and vessels length. For each characteristic, 40 measurements were performed in each sample aiming at obtaining the averages per sample.

The recommendations of the IAWA Committee (IAWA, 1989) were followed for the anatomical study.

\subsection{Statistical analysis}

The completely randomized design was used for statistical analysis, following the model $Y_{i j}=\mu+t_{i}+e_{i j}$, where: $Y_{i j}=$ value of the variable tested under the $i$-th level of treatment; $\mu=$ the overall average of the experiment for the variable; $t_{i}=$ effect of the $\mathrm{i}$-th level of treatment; $e_{i j}=$ random error.

The analysis of variance (ANOVA) at 5\% significance was performed to test the hypothesis of equality between averages found in juvenile and mature woods for initial moisture, basic density, fibers length, fibers width, fibers wall thickness, fibers lumen diameter, vessel elements length, vessels diameter, diameter of ray-vessel pits and vessels frequency.

Some data sets did not meet the assumptions of ANOVA and the Mann-Whitney test at 5\% significance was applied at $5 \%$ significance level to test the hypothesis of similarity between the averages of drying times, drying rates and end check scores found for juvenile and mature woods.

\section{RESULTS AND DISCUSSION}

\subsection{Drastic drying test}

Table 3 presents the averages of initial moisture and basic density of the specimens from the juvenile and mature E. cloeziana woods made for the drastic drying test at $100^{\circ} \mathrm{C}$.

No statistical difference was observed between basic densities and initial moistures of juvenile and mature woods, showing that these wood properties did not vary greatly in the pith-to-bark direction. Paes et al. (2015) found average of 0.770 g. $\mathrm{cm}^{-3}$ in the intermediary heartwood, $0.890 \mathrm{~g} . \mathrm{cm}^{-3}$ in the external heartwood and 
$0.820 \mathrm{~g} . \mathrm{cm}^{-3}$ in the sapwood of E. cloeziana. Taking to account the limit between juvenile and mature woods estimated by Souza et al. (2017), established as the fourteenth growth ring and considered in the present study, it is possible that most of the heartwood is part of the juvenile wood, increasing its average basic density. The principal heartwood characteristic is the presence of extractives, Barrichelo \& Brito (1984) showed that there is a positive correlation between the extractives content and the density of the wood.

There was also no statistic difference between juvenile and mature wood regarding the initial moisture. Zanuncio et al. (2015) state that there is a strong inverse correlation between the basic density of wood and its initial moisture. Consequently, the statistical similarity between the basic densities of the juvenile and mature woods justifies the similarity between their initial moistures.

Soares et al. (2016), studying 37-year-old E. saligna, found a statistically significant difference between juvenile and mature wood in terms of basic density $\left(0.636\right.$ g.cm ${ }^{-3}$ and 0.735 g.cm $\left.{ }^{-3}\right)$ and initial moisture (84.2\% and $62.6 \%)$, this result being different from that seen in Table 3. Soares et al. (2016) estimated the limit between juvenile and mature E. saligna wood as being in the eighth growth ring. This difference in juvenile and mature segregation ages may justify the differences between the results explored here and those presented by these authors. The basic densities found by Soares et al. (2016) are lower than those shown in
Table 3, while the initial moistures presented by these authors are higher than the initial moisture found in the present study.

The averages for drying time, drying rate and end check score found for juvenile and mature E. cloeziana wood specimens subjected to drastic drying are presented in Table 4.

As observed in Table 4, the total drying time (T1) was $21 \%$ lower in the juvenile than in the mature wood. Consequently, the juvenile wood presented total drying rate (R1) 26\% higher than the mature wood. These results indicate that drying occurs, generally, more quickly in juvenile wood than in mature wood, even though the juvenile wood is heartwood and the densities of juvenile and mature wood are similar. Soares et al. (2016) found a similar result when studying 37-year-old E. saligna, but with a greater magnitude difference, with $\mathrm{T} 1$ being about 30\% lower and R1 $68 \%$ higher in juvenile wood than in mature wood.

The drying time of initial moisture up to $30 \%$ (T2) deals with the time required to move the free water from the inside to the outside of the wood. The T2 did not differ statistically between juveniles and mature woods. This may be associated to the observed similarity for initial moisture of the specimens (Table 3), taking similar time to reach $30 \%$ moisture. This result differs from that found by Soares et al. (2016), which reported that there is a $25 \%$ difference between juvenile and mature wood for T2, being higher in juvenile wood. Soares et al. (2016) attributed this result to the difference

Table 3. Averages of initial moisture and basic density in juvenile and mature Eucalyptus cloeziana wood specimens subjected to drastic drying test.

\begin{tabular}{cccc} 
Wood & Basic density $\left(\mathbf{g} \cdot \mathbf{c m}^{-3}\right)$ & Initial moisture (\%) & Number of specimens \\
\hline Juvenile & 0.827 & 55.59 & 12 \\
Mature & 0.849 & 51.87 & 12 \\
Calculated F & $0.83^{\text {ns }}$ & $1.44^{\text {ns }}$ & - \\
\hline
\end{tabular}

ns $=$ not significant at $5 \%$.

Table 4. Averages found for the variables of drastic drying test in juvenile and mature Eucalyptus cloeziana wood.

\begin{tabular}{lcccccccccc}
\multicolumn{1}{c}{ Wood } & T1 & T2 & T3 & R1 & R2 & R3 & C1 & C2 & C3 \\
Juvenile & 11.50 & 2.50 & 9.00 & 0.0174 & 0.0446 & 0.0109 & 4.00 & 3.83 & 4.00 \\
Mature & 14.50 & 2.00 & 12.50 & 0.0138 & 0.0472 & 0.0082 & 3.50 & 2.50 & 3.50 \\
Calculated U & $18.0^{*}$ & $72.0^{\text {ns }}$ & $0.0^{*}$ & $26.5^{*}$ & $64.5^{\text {ns }}$ & $10.0^{*}$ & $51.0^{\text {ns }}$ & $34.5^{*}$ & $51.0^{\text {ns }}$ \\
\hline
\end{tabular}

$\mathrm{T} 1$ = drying time of IM up to $5 \%(\mathrm{~h}) ; \mathrm{T} 2=$ drying time from IM to $30 \%(\mathrm{~h}) ; \mathrm{T} 3=$ drying time from $30 \%$ to $5 \%$ (h); R1 = drying rate of IM up to $5 \%\left(\mathrm{~g} \cdot \mathrm{cm}^{-2} \cdot \mathrm{h}^{-1}\right) ; \mathrm{R} 2=$ drying rate of IM up to $30 \%\left(\mathrm{~g} \cdot \mathrm{cm}^{-2} \cdot \mathrm{h}^{-1}\right) ; \mathrm{R} 3=$ drying rate from $30 \%$ to $5 \%\left(\mathrm{~g} \cdot \mathrm{cm}^{-2} \cdot \mathrm{h}^{-1}\right) ; \mathrm{C} 1=$ end check of IM up to 5\% (score); C2 = end check of IM up to 30\% (score); C3 = end check from 30\% to 5\% (score); ns = not significant at $5 \%$; ${ }^{*}=$ significant at $5 \%$. 
of $26 \%$ of initial moisture between the juvenile and mature wood. The wetter juvenile wood takes more time to lose all the free water present in the intercellular spaces and lumen of the cells.

The drying rate of initial moisture up to $30 \%$ (R2) was statistically similar for both types of wood, indicating the movement of free water at similar rates in juvenile and mature woods, corroborating with Soares et al. (2016).

The drying time from $30 \%$ to $5 \%$ moisture (T3) indicates the time required for the adsorption water moving from the inside to the outside of wood and was $39 \%$ higher in the mature wood that in juvenile wood. Soares et al. (2016) reported that T3 was $42 \%$ higher in the mature wood that in juvenile wood of E. saligna.

The T3 was responsible for most of the time elapsed for total drying of wood, representing $78 \%$ and $86 \%$ for juvenile and mature woods, respectively. This shows that the adsorption water release is slower in the wood in comparison to the free water. Capillary forces, based on the Hagen-Poiseuille's Law, cause the flow of free water. In turn, adsorption water movement occurs through the cell wall due to the moisture gradient and diffusion (Kollmann \& Côté, 1968). The difference between the capillary movement and the diffusion movement is that the latter is a slow process because it occurs simultaneously diffusion of vapor through the cell cavities and diffusion of adsorption water in the cellular walls of the wood (Kollmann \& Côté, 1968).

Concerning the drying rate from $30 \%$ to $5 \%$ moisture (R3), it was 33\% higher in the juvenile than in the mature wood, following the tendency found by Soares et al. (2016). Studying E. saligna for R3, the authors reported that R3 was $62 \%$ higher in the juvenile wood than in the mature wood.

R3 was lower than R1 and R2 for both analyzed woods. This is related to the same factor cited above for $\mathrm{T} 3$ regarding the release of adsorption water.

With regard to the end check observed in the drastic drying test, no differences were found between juvenile and mature woods for the total end check score (C1) and those occurring in the range from 30\% to 5\% moisture (C3). However, the end check score between initial moisture and 30\% moisture (C2) in juvenile wood was higher than in mature wood, according to Table 3. This result indicates that juvenile E. cloeziana wood is more susceptible than mature wood to the onset of end check in the initial stage of the drying. This is plausible, since juvenile wood is composed of fibers with less wall thickness (Panshin \& De Zeeuw, 1980), which makes it less mechanically resistant than the mature wood.

According to Kollmann \& Côté (1968), checks arise when the wood reaches moistures below the fibers saturation point ( $30 \%$ moisture) is common. This is related to the fact that moisture release from the peripheral regions of a wood piece is faster when compared to the migration of the moisture from the center of that piece to its peripheral regions. In this way, the periphery of the piece reaches moistures below the fibers saturation point and begins to contract before the internal part of the piece. This movement causes the tensions that, when surpassing the mechanical resistance of the wood, lead to the occurrence of end check. In the present study, the highest incidence of check was verified after 30\% moisture (C3), supporting this theory. Soares et al. (2016) observed the same tendency in specimens from mature E. saligna wood. Eleoterio et al. (2015) found C2 similar to C3 in the specimens of all Eucalyptus species evaluated in their study.

It is noteworthy that in the juvenile wood the end check appeared with greater intensity in $83 \%$ of the number of specimens, which led to a larger end check score, even though the other $17 \%$ of them were free of this defect. In the mature wood, the defect manifested in all the specimens, but with less intensity, leading to a lower end check score.

\subsection{Relations between anatomy and behavior of woods subjected to drying}

The averages found for the anatomical characteristics of fibers and vessels are presented in Table 5.

There was no statistical difference between juvenile and mature woods for average fibers lumen diameter, vessel elements length and diameter of ray-vessel pits.

The averages of fibers length, fibers width, fibers wall thickness and vessels diameter were higher in mature wood, while vessels frequency was higher in juvenile wood. This result corroborates the one stated by Trevisan et al. (2017). The authors found averages of $1.33 \mathrm{~mm}, 25.48 \mu \mathrm{m}$ and $5.76 \mu \mathrm{m}$ (FL, FW and FWT, respectively) in mature wood, statistically higher than the averages of $0.96 \mathrm{~mm}, 21.20 \mu \mathrm{m}$ and $4.00 \mu \mathrm{m}$ found in the juvenile wood. 
Table 5. Anatomical characteristics of fibers and vessels in the juvenile and mature Eucalyptus cloeziana woods.

\begin{tabular}{lclllllcc}
\multicolumn{1}{c}{ Wood } & $\begin{array}{c}\text { FL } \\
(\mathbf{m m})\end{array}$ & $\begin{array}{c}\text { FW } \\
(\boldsymbol{\mu m})\end{array}$ & $\begin{array}{c}\text { FLD } \\
(\boldsymbol{\mu m})\end{array}$ & $\begin{array}{c}\text { FWT } \\
(\boldsymbol{\mu m})\end{array}$ & $\begin{array}{c}\text { VEL } \\
(\mathbf{m m})\end{array}$ & $\begin{array}{c}\text { VD } \\
(\mathbf{m m})\end{array}$ & $\begin{array}{c}\text { VF } \\
\left(\text { vessels } / \mathbf{m m}^{2}\right)\end{array}$ & $\begin{array}{c}\text { DRVP } \\
(\boldsymbol{\mu m})\end{array}$ \\
Juvenile & 1.08 & 18.49 & 6.96 & 5.76 & 0.488 & 0.087 & 7.15 & 7.03 \\
Mature & 1.34 & 20.60 & 7.08 & 6.75 & 0.492 & 0.099 & 4.15 & 7.27 \\
Calculated F & $61.38^{\star}$ & $13.93^{\star}$ & $0.21 \mathrm{~ns}$ & $19.41^{\star}$ & $0.02 \mathrm{~ns}$ & $7.36^{\star}$ & $55.97^{\star}$ & $0.12 \mathrm{~ns}$ \\
\hline
\end{tabular}

$\mathrm{FL}=$ fibers length; FW = fibers width; FLD = fibers lumen diameter; FWT = fibers wall thickness; VEL = vessel elements length; $\mathrm{VD}=$ vessels diameter $\mathrm{VF}=$ vessels frequency; $\mathrm{DRVP}=$ Diameter of ray-vessel pits; $\mathrm{ns}=$ not significant at $5 \% ;{ }^{*}=$ significant at $5 \%$.

The anatomical differences observed in Table 5 were related to differences in drying rate (R1 and $\mathrm{R} 3$ ) and end check (C2) observed in Table 4 between juvenile and mature woods, aiming to clarify the possible influence of the wood anatomy on the obtained results with drying.

In juvenile wood, the fibers length and fibers wall thickness were smaller than in the mature wood. However, the drying rates of initial moisture up to $5 \%$ (R1) and from $30 \%$ to $5 \%$ moisture (R3) were higher in the juvenile wood. This shows an inverse relation between the fibers length and releases of total water and adsorption water. Ahmed \& Chun (2011) reported that the increase in fibers length reduced the liquid release in Tectona grandis wood, thus corroborating with the present study.

The fibers wall thickness was inversely proportional to the drying rate. This inverse relation may occur due to the relation between the fibers length and the fibers wall thickness. The cambium physiologically mature produces fibers with higher length and cell wall thickness (Panshin \& De Zeeuw, 1980), so that the thicker the fiber cell wall, the slower the water release by diffusion, when necessary.

When observing the behavior of fibers length and fibers wall thickness, a negative relation between the proportion of end check and these anatomical characteristics is seem, i.e., the mature wood showed higher fibers length and fibers wall thickness and lower onset of end check (C2). This relation is plausible, considering that the fibers wall is primarily responsible for the mechanical strength of the wood, and the thicker the fibers wall, the higher its strength tends to be.

In the juvenile wood, the vessels diameter was smaller and the vessels frequency was higher. Drying rates followed the tendency observed for vessels frequency, so that their reduction in mature wood also decreased drying rates $\mathrm{R} 1$ and $\mathrm{R} 3$, indicating total water and adsorption water release slower in the mature wood.

A direct relation between the vessels frequency and the end check score was observed, which were higher in juvenile wood. The vessels diameter was lower in the juvenile wood than in the mature wood, but showed a higher end check score (C2), indicating an inverse relation. Gacitúa et al. (2007) and Valenzuela et al. (2012) analyzed the occurrence of check in E. nitens wood aged 16 and 12 years, respectively, and stated that the area of vessels per area of interest is directly related to the occurrence of check in wood. This phenomenon is attributed to the higher concentration of stresses generated around the vessels in the materials with larger area of vessels per area of interest, leading to tissue rupture. However, the influence of vessels frequency and diameter on the parameter area of vessels per area of interest varies according to the studied material. For example, Gacitúa et al. (2007) found higher area of vessels per area of interest in the material that showed higher vessels frequency, whereas Valenzuela et al. (2012) observed higher area of vessels per area of interest in the material with higher vessels diameter.

\section{CONCLUSIONS}

The juvenile E. cloeziana wood behaves differently from the mature wood when subjected to drying, being the drying rate higher and the drying time lower in juvenile wood. There is indications that this wood is more susceptible to the occurrence of end check.

Smaller fibers length and fibers wall thickness, higher vessels frequency and smaller vessels diameter found in juvenile wood were associated with higher total drying rate and of adsorption water. Higher fibers length and fibers wall thickness, lower vessels frequency and higher vessels diameter found in mature wood were associated with lower occurrence of end check. 


\section{ACKNOWLEDGEMENTS}

The authors are grateful to CAPES and CNPq (Process 311574/2013-0) for the grants and financial support during this work.

\section{SUBMISSION STATUS}

Received: 17 aug., 2017

Accepted: 31 july, 2018

\section{CORRESPONDENCE TO}

\section{Bruno Charles Dias Soares}

Departamento de Ciências Florestais, Universidade Federal de Lavras UFLA, Av. Doutor Sylvio Menicucci, 1001, Bairro Presidente Kennedy, CEP 37200-000, Lavras, MG, Brasil e-mail: bruno.soares_18@hotmail.com

\section{FINANCIAL SUPPORT}

Conselho Nacional de Desenvolvimento Científico e Tecnológico (Grant/Award Number: '311574/2013-0’).

\section{REFERENCES}

Ahmed SA, Chun SK. Permeability of Tectona grandis L. as affected by wood structure. Wood Science and Technology 2011; 45(3): 487-500. http://dx.doi.org/10.1007/s00226010-0335-5.

Associação Brasileira de Normas Técnicas - ABNT. NBR 11941-02: determinação da densidade básica em madeira. Rio de Janeiro: ABNT; 2003.

Barbosa CG, Lima JT, Rosado SCS, Trugilho PF. Elaboração de programa de secagem para madeiras de clones de híbridos de Eucalyptus spp. Cerne 2005; 11(1): 40-48.

Barrichelo LEG, Brito JO. Variabilidade longitudinal e radial da madeira de Eucalyptus grandis. In: Anais do XVII Congresso Anual da ABTCP; 1984; São Paulo. São Paulo: ABTCP; 1984. p. 403-409.

Eleoterio JR, Bagattoli TR, Hornburg KF, Silva CMK. Secagem drástica de madeiras de Eucalyptus e Corymbia fornece informações para a elaboração de programas de secagem. Pesquisa Florestal Brasileira 2015; 35(84): 451-457. http://dx.doi.org/10.4336/2015.pfb.35.84.696.

Franklin GL. Preparation of thin sections of synthetic resins and wood-resin composites, and a new macerating method for wood. Nature 1945; 155(3924): 51. http:// dx.doi.org/10.1038/155051a0.

Gacitúa W, Ballerini A, Laserre JP, Bahr D. Nanoindentaciones y ultraestructura em madera de Eucalyptus nitens con micro y meso fracturas. Maderas. Ciencia y Tecnología 2007; 9(3): 259-270.

International Association of Wood Anatomists - IAWA. List of microscopic features for hardwood identification. IAWA Bulletin 1989; 10(3): 210-232.

Kollmann FFP, Côté WA. Principles of wood science and technology: solid wood. Vol. 1. New York: Sprigerm; 1968. http://dx.doi.org/10.1007/978-3-642-87928-9.

Paes JB, Brocco VF, Moulin JC, Motta JP, Alves RC. Efeitos dos extrativos e da densidade na resistência natural de madeiras ao térmita Nasutitermes corniger. Cerne 2015; 21(4): 569-578. http://dx.doi.org/10.1590/01047760201 521041849 .

Panshin AJ, De Zeeuw C. Textbook of wood technology. 4th ed. New York: Mc-Graw-Hill; 1980.

Pratt GH. Timber drying manual. London: Department of the Environment; 1974.

Soares BCD, Lima JT, Silva JRM. Analysing the drying behavior of juvenile and mature Eucalyptus saligna wood in drastic drying test for optimal drying schedule. Maderas. Ciencia y Tecnología 2016; 18(4): 543-554.

Souza MT, Lima JT, Soares BCD, Goulart SL, Lima LC. Delimitação estatística dos lenhos juvenil e adulto em quatro espécies de Eucalyptus e Corymbia. Scientia Forestalis 2017; 45(116): 611-618. http://dx.doi.org/10.18671/scifor. v45n116.02.

Trevisan R, Rosa M, Haselein CR, Santini EJ, Gatto DA. Dimensões das fibras e sua relação com a idade de transição entre lenho juvenil e adulto de Eucalyptus grandis W. Hill ex Maiden. Ciência Florestal 2017; 27(4): 1385-1393. http://dx.doi.org/10.5902/1980509830220.

Valenzuela CP, Bustos AC, Lasserre JP, Gacitúa EW. Fracturas en madera de Eucalyptus nitens: efecto de las propiedades mecánicas a nivel ultraestructural y de la anatomía celular. Maderas. Ciencia y Tecnología 2012; 14(2): 225-238. http://dx.doi.org/10.4067/S0718221X2012000200009.

Vidaurre G, Lombardi LR, Oliveira JTS, Arantes MDC. Lenho juvenil e adulto e as propriedades da madeira. Floresta e Ambiente 2011; 18(4): 469-480. http://dx.doi. org/10.4322/floram.2011.066.

Zanuncio AJV, Carvalho AG, Silva LF, Lima JT, Trugilho PF, Silva JRM. Predicting moisture content from basic density and diameter during air drying of Eucalyptus and Corymbia logs. Maderas. Ciencia y Tecnología 2015; 17(2): 335-344. 